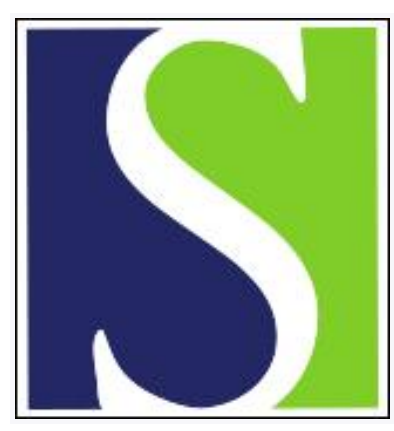

Scand J Work Environ Health 1978;4(1):13-19

https://doi.org/10.5271/sjweh.2759

Issue date: 1978

\title{
Load on back in concrete reinforcement work.
}

by Saari J, Wickström G

Key terms: back; back load; concrete reinforcement work; concrete work; dynamic load; load; static load

This article in PubMed: www.ncbi.nlm.nih.gov/pubmed/663570

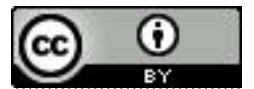




\title{
Load on back in concrete reinforcement work
}

\author{
by JORMA SAARI, Dr. Tech., ${ }^{1}$ and GUSTAV WICKSTRÖM, M.D. ${ }^{2}$
}

\begin{abstract}
SAARI, J. and WICKSTROัM, G. Load on back in concrete reinforcement work. Scand. j. work environ. \& health 4 (1978): suppl. 1, 13-19. The demanids of work on the back of concrete reinforcement workers was determined through 4,327 observations of the various work postures and the weights lifted. Static loads from forward-leaning and bent-double postures were found to be common. In the preparation of intermediate and thick rods, forward-leaning was required for more than a third of the total work time, while one central assembly task required work in the bent-double posture for $58 \%$ of the total work time. The dynamic loads were of less importance, even though weights over $30 \mathrm{~kg}$ were lifted about $15 \%$ of the time in the preparation tasks and momentary forces approaching $1,000 \mathrm{~N}$ were occasionally needed. The bent-double posture, combined with or quickly followed by additional strain from, for example, weight lifting or slipping, was considered the most probable cause for possible signs of accelerated lumbar disc degeneration, while also the forward-leaning postures could be responsible for reversible low-back symptoms.
\end{abstract}

Key words: back load, concrete reinforcement work, dynamic, static.

The reinforcement of concrete structures with iron or steel is a building technique nearly as old as the use of concrete. The work consists of the preparation and assembly of steel rods. "Preparing" involves pulling long steel rods out of a stack (fig. 1), cutting them to the required length (fig. 2), and bending them according to sketches. "Assembling" the steel rods means tying the rods together to form a steel skeleton (figs. 3 and 4), on which concrete is later poured by other workers.

Concrete reinforcement work puts a substantial dynamic and static load on the musculoskeletal organs. Low-back symptoms are frequent in the reinforcement profession, and many workers have to leave active work before the age of retire-

1 Institute of Occupational Health, Helsiniki, Finland.

2 Turku Regional Institute of Occupational Health, Turku, Finland. ment at 65 years. The aim of this study was to identify the phases of concrete reinforcement work that are the most demanding for the back (10).

\section{METHODS}

The use of different work postures and the handling of weights was measured from the observation of workers at regular intervals on two office construction sites. The observation periods were scattered throughout the construction process so that all the different types of reinforcement work were included. Adopted work postures and handled loads were the main variables studied, but the structure to be built, the phase of work, the surface on which the worker moved, as well as the climate, were also recorded. The observations were carried out by a specially trained physiotherapist. 


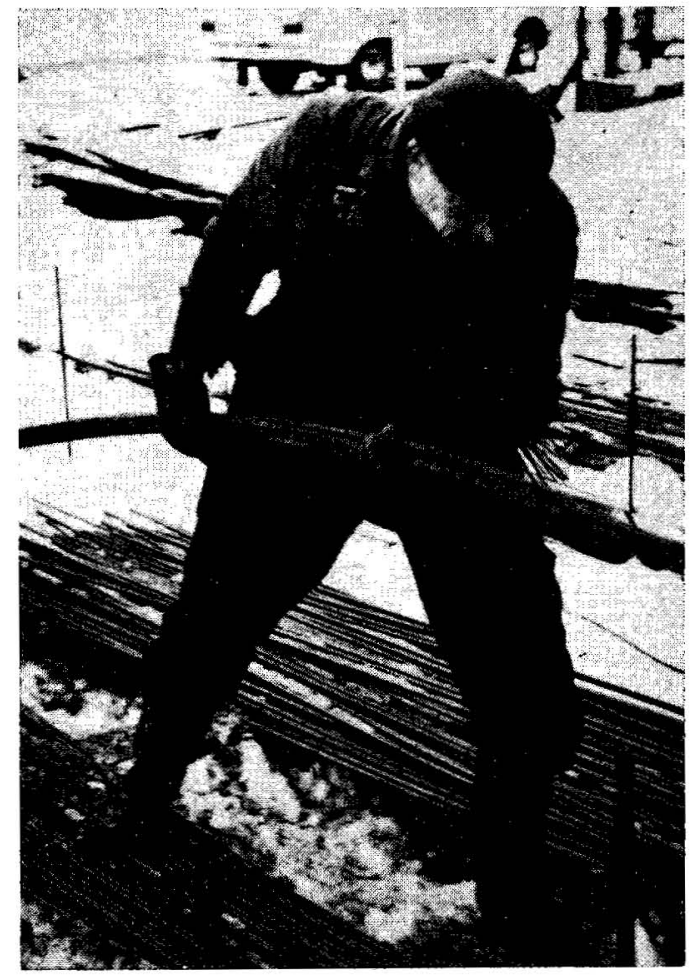

Fig. 1. Pulling steel rods from the stack.

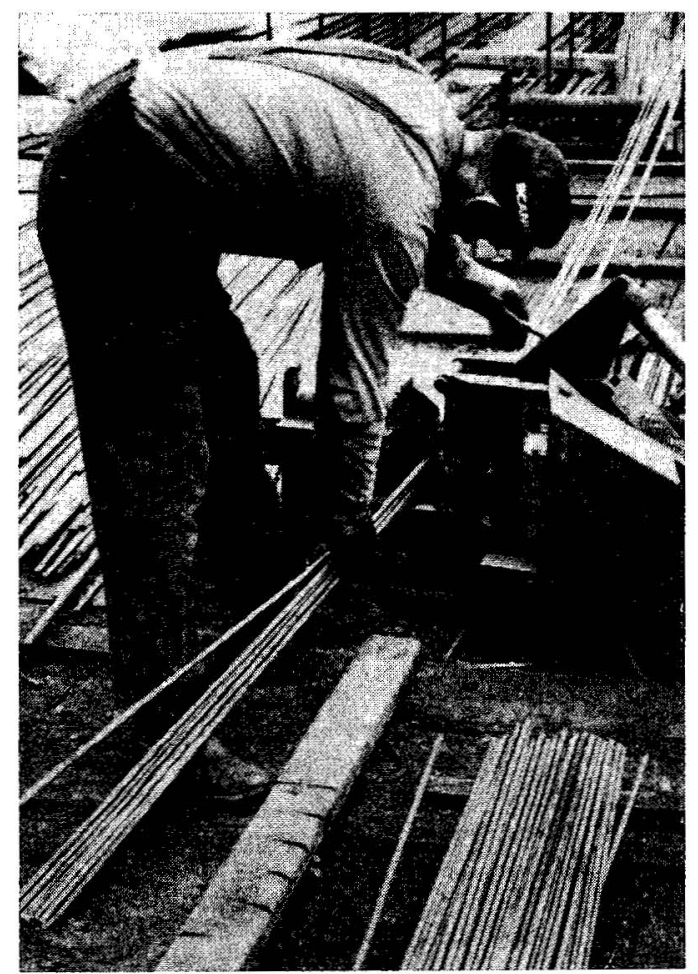

Fig. 2. Bent-double posture when cutting steel rods.

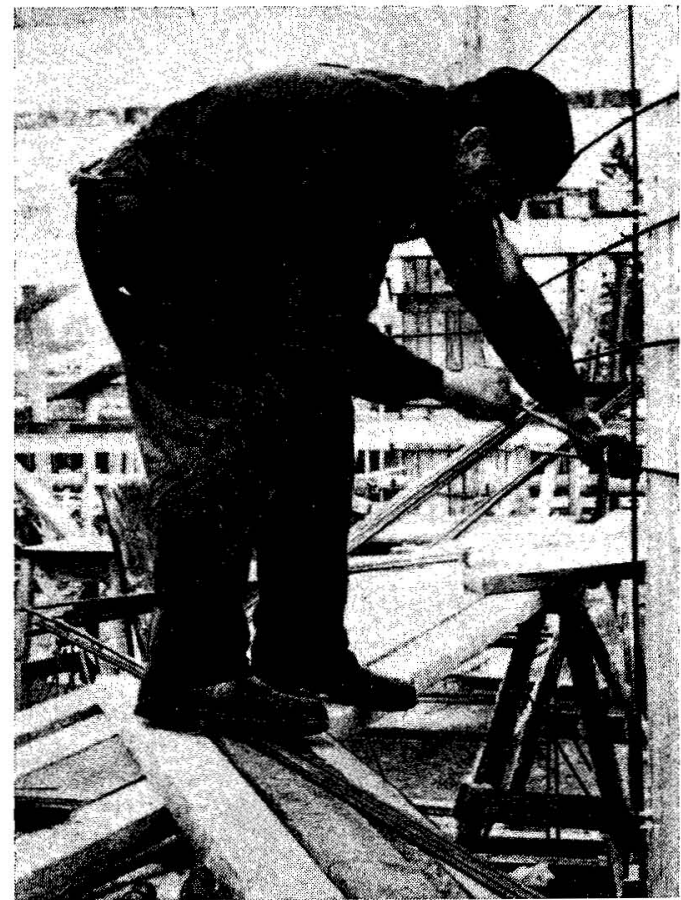

Fig. 3. Forward-leaning posture in the assembly of wall structures.

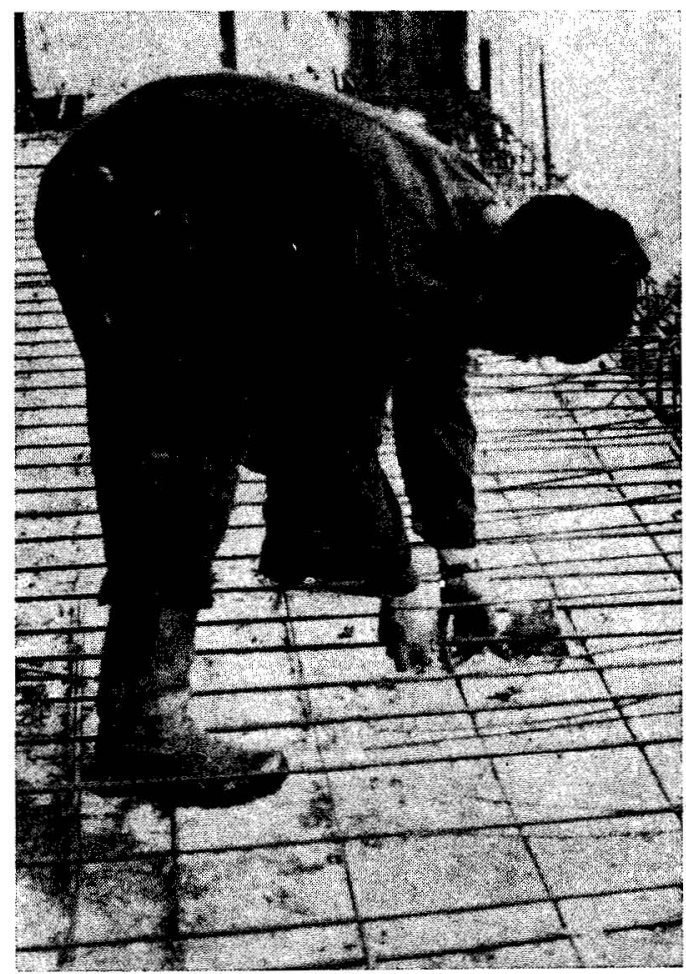

Fig. 4. Bent-double posture in the assembly of floor structures. 
Postures and movements were classified as follows:

\begin{tabular}{|c|c|}
\hline 1 & $\begin{array}{l}\text { standing straight (bending forward } \\
\bar{Z} 10^{\circ} \text { ) }\end{array}$ \\
\hline$g$ & $\begin{array}{l}\text { leaning forward (bending forward } \\
11^{\circ}-90^{\circ} \text { ) }\end{array}$ \\
\hline on & bent-double (bending forward $>90^{\circ}$ ) \\
\hline$g$ & sitting \\
\hline 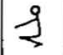 & squatting \\
\hline 空 & kneeling \\
\hline$\stackrel{10}{7}$ & lifting \\
\hline$\leftrightarrow \AA$ & walking \\
\hline 간 & other postures or movements \\
\hline
\end{tabular}

The weights handled at work were classified as $<5 \mathrm{~kg}, 5-30 \mathrm{~kg}$, and $>30 \mathrm{~kg}$. By the previous weighing of typical loads, the physiotherapist was trained to assess the weights by observation. Forces in pulling and bending steel rods were measured with a string dynamometer.

In order to determine the frequency of various work postures and weight handling, the physiotherapist made observations every $30 \mathrm{~s}$. In most cases two workers were observed at the same time. The observation period for each work phase was determined to be long enough to guarantee an error of less than $5 \%$ at the $95 \%$ confidence level. Altogether the effective observation time was $35 \mathrm{~h}$.

Eight male workers, aged 43 to 54 years and between 172 and $182 \mathrm{~cm}$ tall, were observed. All of them had been employed as concrete reinforcement workers for more than 10 years. The interindividual variation in adopted work postures was considered very small in comparison to the dependence of posture on the different structures to be built, and it was not evaluated in this study.

In the case of the stooped posture it was not only considered important to determine the frequency of occurrence but also the duration of occurrence, as this might be decisive in the possible appearance of adverse effects.
For the evaluation of possible lumbar movement while the workers were in the stooped posture, a few minutes of tying work was filmed. The relative position of the shoulder and hip levels was analyzed in slow motion.

\section{RESULTS}

The tasks involved in the preparation of steel rods constitute about half of reinforcement work, while the assembling tasks make up the other half. The proportion of different tasks within these two main work phases vary however according to the type of building under construction. In this study the preparation of steel rods was covered by 2,217 observations, and the rod assembly by 2,020 observations.

\section{Work postures and movements}

Standing straight was the dominant posture while the workers prepared thin rods, and it also made up nearly half of the work time during the preparation of medium and thick rods. Leaning forward was common in the preparation of medium and thick rods, while the bent-double posture was rarely observed during preparatory work (table 1).

In the assembly tasks the postures and movements varied considerably according to the structure to be tied. Standing upright was the most common during the tying of columns and walls, but accounted for only a third or less of the work time during the tying of floor and beam structures. A forward leaning posture was adopted over $10 \%$ of the time in the tying of wall and floor structures and over $20 \%$ of the time when the workers tied beams. Stooping was the dominant posture in the tying of floor constructions (fig. 4); it was also observed during the tying of beams and wall structures. Kneeling on one or both knees comprised over $10 \%$ of the time during the tying of beams. The squatting posture was rare and was mostly used for the tying of wall structures (table 2).

The bent-double or stooped posture in the tying of floor structures was adopted for a median time of $70 \mathrm{~s}$, but periods as 
Table 1. Work postures and movements observed in the preparation of steel rods of different thickness $(\%)$.

\begin{tabular}{|c|c|c|c|c|}
\hline \multirow{2}{*}{\multicolumn{2}{|c|}{ Work posture or movement }} & \multicolumn{3}{|c|}{ Diameter of steel $\operatorname{rod}^{a}$} \\
\hline & & $\begin{array}{c}6 \mathrm{~mm} \\
(\mathrm{~N}=785)\end{array}$ & $\begin{array}{l}8-12 \mathrm{~mm} \\
(\mathrm{~N}=729)\end{array}$ & $\sum_{(\mathrm{N}=703)} 15 \mathrm{~mm}$ \\
\hline \& & Standing straight & 88 & 43 & 46 \\
\hline$\lambda$ & Leaning forward & 3 & 36 & 37 \\
\hline O & Bent double & 2 & 2 & 4 \\
\hline 的 & Sitting & 0 & 2 & 0 \\
\hline j & Squatting & 0 & 0 & 1 \\
\hline 空 & Kneeling & 0 & 0 & 0 \\
\hline 19 & Lifting & 1 & 5 & 3 \\
\hline$\rightarrow \AA$ & Walking & 6 & 12 & 9 \\
\hline if & Others & 0 & 0 & 0 \\
\hline Total & & 100 & 100 & 100 \\
\hline
\end{tabular}

a $\mathrm{N}=$ number of observations.

long as $4 \mathrm{~min}$ were measured several times (fig. 5). The film analysis showed that the stooped work posture was not altogether static. Even if the worker did not straighten up, minor changes in the degree of stooping continually occurred. While the hips maintained a constant height above the floor, the shoulder level

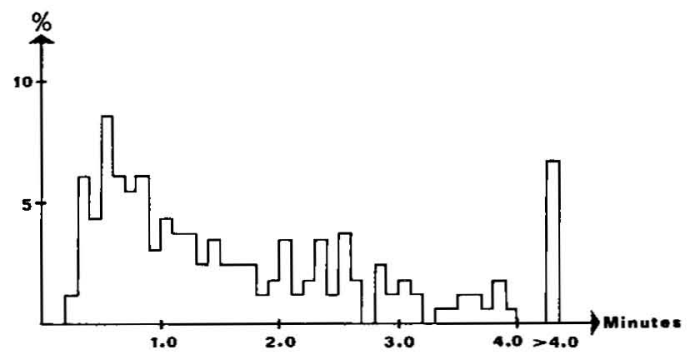

Fig. 5. Frequency of distribution for the duration of continuous stooping in the tying of floor structures. The measurements were made from the work of five men; the total number of measurements was 164 . rose and fell. An example of this movement is shown in fig. 6 .

\section{Weight handling}

Weights over $30 \mathrm{~kg}$ were handled about $15 \%$ of the time in the preparation of

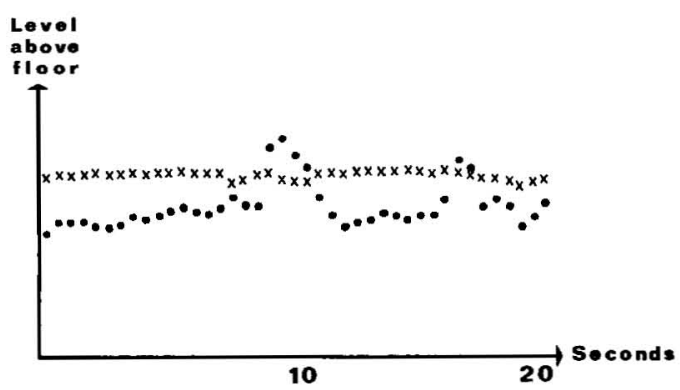

Fig. 6. Level of shoulders (•) in comparison to level of hips $(x)$ during continuous stooping while a worker ties floor structures. 
Table 2. Work postures and movements observed in the rod assembly of different structures $(\%)$.

\begin{tabular}{|c|c|c|c|c|c|c|}
\hline \multirow{2}{*}{\multicolumn{2}{|c|}{ Work posture or movement }} & \multicolumn{5}{|c|}{ Structure a } \\
\hline & & $\begin{array}{c}\text { Wall } \\
(\mathrm{N}=308)\end{array}$ & $\begin{array}{c}\text { Floor } \\
(\mathrm{N}=440)\end{array}$ & $\begin{array}{l}\text { Beam } \\
\text { at or } \\
\text { above } \\
\text { floor } \\
\text { level } \\
(\mathrm{N}=400)\end{array}$ & $\begin{array}{c}\text { Beam } \\
\text { below } \\
\text { floor } \\
\text { level } \\
(\mathrm{N}=592)\end{array}$ & $\begin{array}{l}\text { Column } \\
(\mathrm{N}=280)\end{array}$ \\
\hline & Standing straight & 61 & 21 & 27 & 33 & 78 \\
\hline$\lambda$ & Leaning forward & 16 & 11 & 29 & 24 & 7 \\
\hline on & Bent double & 8 & 58 & 11 & 15 & 3 \\
\hline I & Sitting & 0 & 0 & 0 & 0 & 0 \\
\hline 3 & Squatting & 8 & 2 & 5 & 4 & 0 \\
\hline 空 & Kneeling & 0 & 0 & 20 & 11 & 0 \\
\hline 17 & Lifting & 1 & 1 & 3 & 1 & 5 \\
\hline$\stackrel{-1}{\mathbf{f}}$ & Walking & 6 & 7 & 5 & 6 & 7 \\
\hline 证 & Others & 0 & 0 & 0 & 6 & 0 \\
\hline Total & & 100 & 100 & 100 & 100 & 100 \\
\hline
\end{tabular}

a $\mathbf{N}=$ number of observations.

Table 3. Handling of weights in the preparation and assembly of steel rods $(\%)$.

\begin{tabular}{lccc}
\hline & \multicolumn{3}{c}{ Weight } \\
\cline { 2 - 4 } Task a & $<5 \mathrm{~kg}$ & $5-30 \mathrm{~kg}$ & $>30 \mathrm{~kg}$ \\
\hline Preparation & & & \\
Diameter of rods $6 \mathrm{~mm}(\mathrm{~N}=785)$ & 79 & 17 \\
Diameter of rods 8-12 mm (N =729) & 77 & 13 & 10 \\
Diameter of rods $\geq 15 \mathrm{~mm}(\mathrm{~N}=703)$ & 79 & 9 & 12 \\
Assembly & 97 & 3 & 0 \\
Wall (N = 308) & 93 & 6 & 1 \\
Floor (N = 440) & 95 & 5 & 0 \\
Beam at floor level (N = 400) & 93 & 7 & 0 \\
Beam under floor level $(\mathrm{N}=592)$ & 80 & 17 & 3 \\
Column (N = 280) & & & \\
\hline
\end{tabular}

a $\mathrm{N}=$ number of observations.

steel rods (table 3). The force needed to lift the steel rods and drag them out of the stack varied according to the dia- meter and number of rods lifted, and according to the orderliness of the stack as well. A few measurements indicated 
that the force needed to lift 15 rods (diameter $10 \mathrm{~mm}$, length $10-12 \mathrm{~m}$ ) was about $750 \mathrm{~N}$, while the horizontal force needed to drag these rods to the cutting machine could rise to $700 \mathrm{~N}$. As, in general, the workers picked up less than 15 rods of this size, the estimated forces can be considered maximal under ordinary circumstances.

In the assembly tasks, weights over $30 \mathrm{~kg}$ were seldom handled.

\section{DISCUSSION}

Thorough epidemiologic studies have definitely shown that heavy work has a degenerative effect on the lumbar spine (1, $4,5,11$ ), but the specific work components responsible for the acceleration of lumbar degeneration have not yet been clearly defined (12). The forward leaning posture causes or aggravates low-back symptoms (14), and the bent-double posture may contribute to premature lumbar degeneration (6).

The reinforcement of concrete involves several tasks, many of which put considerable load on the back. A questionnaire covering the skilled occupations in the Finnish construction industry showed that a larger proportion of concrete reinforcement workers reported harmful effects from difficult work postures than any other occupational group (13).

The only previous study on ergonomic problems in concrete reinforcement work is, to our knowledge, that made by Hansson et al. (3), who measured oxygen consumption in different work phases and forces exerted when various tools were used.

The present study covered the construction of office buildings, which represents an intermediate form of reinforcement work. Apartment houses require lighter steel structures and are often predominantly made of prefabricated concrete elements, while heavy constructions, like factories, require heavier steel structures, which are largely built on the construction sites.

We found that two phases of concrete reinforcement work put an especially high load on the lumbar spine. The assembly of floor structures involves a great postural load because of the bent-double work position, while disengagement of the steel rods from the stack and pulling the rods to the cutting machine constitutes a great dynamic load. Of these two loads, the bent-double posture in floor assembly is the more common, and probably the more important, and may be considered the primary characteristic of concrete reinforcement work.

\section{Postural load}

There are several ways to define posture $(7,8,14)$. The classification of postures used in this study is similar to that employed by Rohmert and Schott (9). It reflects the functional state of the intervertebral discs, ligaments, and muscles. "Standing straight" implies minor loads on dises, muscles, and ligaments; "leaning forward," a higher load on discs and a high load on muscles; and "bent double," a high load on discs and ligaments $(2,7)$.

A prolonged bent-double posture causes stretching of the ligaments and may thus decrease the stability of the spine after stooping. In this period the spine may be especially vulnerable to sudden strain, such as slipping. It is also possible that prolonged stooping causes disturbance of the disc nutrition and hence accelerates the degenerative process in the intervertebral discs.

In the present study the proportion of the bent-double work posture was found to be several times higher in concrete reinforcement work than in the repair of trucks and the transportation of ore as reported by Rohmert and Schott (9). In reinforcement work the bent-double position was mostly adopted for about $1 \mathrm{~min}$ at a time, but periods exceeding even 4 min were repeatedly observed.

The assembly of floor structures make up a central part of all assembly work and may constitute the dominating work phase in some projects, like building bridges. Concrete reinforcement workers may thus be predominantly working bent-double for days and weeks, sometimes even for months.

\section{Dynamic load}

The dynamic load on the back derives from the disengagement of the steel rods 
from the stack and the pulling of the rods to the cutting machine.

The disengagement requires heavy lifting in a forward-leaning or bent-double position. If the rods are in good order, the work involved is only one-tenth of that needed during lifting from a disordered stack.

Pulling the rods to the cutting machine first requires a jerk to get the rods moving. This jerk causes a great momentary load on the back. The worker then turns around with the rods already in motion and pulls them to the machine. This action generally constitutes a smaller load on the back. However, pulling the rods on an uneven and often slippery surface implies a risk of slipping and thus exposing the already heavily loaded back structures to a sudden additional load.

Even if the time for exposure to the dynamic loads in the task of preparation is reasonably short, both heavy lifting in forward-bending positions and sudden slipping when the back structures are already loaded have to be considered as hazardous for the low back.

Earlier the steel rods were cut and bent by muscle force. Electrically powered machines were introduced in the 1950 s and are now used on most work sites. The use of prefabricated steel nets and concrete elements started in the 1960s and is still growing. However, a considerable part of reinforcement work is still done by hand on the construction sites. The technical innovations have reduced the dynamic load on the upper extremities of the reinforcement workers by supplying electrical machines for cutting. and bending. Otherwise the performance of different preparation and assembly tasks has not changed much, and the reinforcement workers may be considered to have been exposed to approximately the same type and amount of back load factors during the last 30 years.

\section{REFERENCES}

1. CAPLAN, P., FREEDMAN, L. and CONNELLY, T. Degenerative joint disease of the lumbar spine in coal miners - A clinical and X-ray study. Arthritis rheum. 9 (1966): 5, 693-702.

2. FLOYD, W. F. and SILVER, P. H. S. The function of the erectores spinae muscles in certain movements and postures in man. J. physiol. 129 (1955) 184-203.

3. HANSSON, J.-E., GUHARAY, A. and NILSSON, H. Hantering och bearbetning av armeringsjärn (Byggnadsindustrins forskningsrapporter och uppsatser no. 5). Arbetsmedicinska Institutet, Stockholm 1967. $40 \mathrm{p}$.

4. HULT, L. Cervical, dorsal and lumbar spinal syndromes. Acta orthop. scand. suppl. 17 (1954) $102 \mathrm{p}$.

5. KELLGREN, J. H. and LAWRENCE, J. S. Rheumatism in miners: Part II. X-ray study. Br. j. ind. med. 9 (1952): 3, 197-207.

6 LAWRENCE, J. S. Rheumatism in coal miners: Part III. Occupational factors. $\mathrm{Br}$. j. ind. med. 12 (1955): 3, 243-261.

7. NACHEMSON, A. The load on lumbar disks in different positions of the body. Clin. orthop. 45 (1966) 107-122.

8. PRIEL, V. Z. A numerical definition of posture. Hum. factors 16 (1974): 6, 576584.

9. ROHMERT, W. and SCHOTT, R. Körperstellungen in Fertigungs-, Kfz-Reparaturund Bergbau-Betrieben. Int. Arch. Arbeitsmed. 32 (1974): 3, 149-165.

10. SAARI, J., LAUNIS, M, and WICKSTROMM, G. Betoniraudoittajat. Osa 3, Raudoitustyön ergonominen kuvaus (Työterveyslaitoksen tutkimuksia no. 99). Institute of Occupational Health, Helsinki 1974. 137 p.

11. SCHLOMKA, G. and SCHRÖTER, G. Über die Bedeutung der beruflichen Belastung für die Entstehung der degenerativen Gelenkleiden. $Z$. Gesamte Ind. Med. 3 (1953): 10, 473-476.

12. WICKSTRÖM, G. Effect of work on degenerative back disease: A review. Scand. $j$. work environ. \& health 4 (1978): suppl. 1, $1-12$.

13. WICKSTRÖM, G. and KAUPPINEN-TOROPAINEN, K. Rakennusalan työntekijöiden työolot ja terveydentila (Työterveyslaitoksen tutkimuksia no. 91). Institute of Occupational Health, Helsinki 1974. 154 p.

14. ZUIDEMA, H. Low back pain in work shops. Presented at the 9th European Philips congress on occupational medicine in Hamburg, Germany, October 3rd 1973. $13 \mathrm{p}$. 